\title{
UPAYA PEMERINTAH DALAM MENGURANGI PELANGGARAN TAPAL BATAS INDONESIA-MALAYSIA (studi kasus kabupaten nunukan) Muhammad Fachri Universitas Hasanuddin Mfachri164@gmail.com
}

\begin{abstract}
The border area is one of the national strategic areas, the development of border areas is often faced with various security, defense, economic, social and cultural issues. The vulnerability of violations occurring in the IndonesiaMalaysia border region can cause many problems that arise from illegal border crossers, Smuggling of Goods, Illegal Workers, Terrorism. In this essay investigate the extent of government efforts in reducing border violations in Indonesia-Malaysia border region especially in Nunukan district. This research was conducted by Nunukan Regency in several agencies that handle border issues, Nunukan District Government Office, District Command 0911 of Nunukan, Ministry of Immigration Nunukan District, Navy Command Nunukan District This research was conducted by data collection method (field research), to obtain primary data through interview with the competent party in this research, and by method of literature research, to obtain secondary data through binding legal materials. Post-border crossings in Sei Pancang have a significant impact on border residents who want to pass. This can lead to a large number of illegal borderline subscribers. However, in its implementation in an effort to reduce border violations in the border area the government is faced by many factors that can affect law enforcement, law factors, law enforcement factors, facilities, cultural and community factors.
\end{abstract}

Keywords: Border Area, Government, Law Enforcement.

\begin{abstract}
Abstrak
Kawasan perbatasan merupakan salah satu kawasan strategis nasional, pembangunan kawasan perbatasan seringkali dihadapkan dengan berbagai masalah keamanan, pertahanan, ekonomi, sosial, dan budaya. Rawannya pelanggaran yang terjadi di wilayah perbatasan Indonesia-Malaysia dapat menyebabkan banyaknya masalah yang timbul mulai Pelintas batas illegal, Penyelundupan barang, TKI Ilegal, Terorisme. Di essay ini menyelidiki sejauh mana upaya pemerintah dalam mengurangi pelanggaran tapal batas di kawasan perbatasan Indonesia-Malaysia khususnya di kabupaten Nunukan. Penelitian ini dilakukan Kabupaten Nunukan di beberapa instansi yang menangani masalah
\end{abstract}


perbatasan, Kantor Pemerintahan Daerah Kabupaten Nunukan, Komando Distrik 0911 Kab. Nunukan, Kementerian Keimigrasian Kab. Nunukan, Komando Angkatan Laut Kab. Nunukan. Penelitian ini dilakukan dengan metode pengumpulan data (field research), untuk memperoleh data primer melalui wawancara dengan pihak yang kompeten dalam penelitian ini, dan dengan metode studi literatur (literature research), untuk memperoleh data sekunder melalui bahan-bahan hukum yang mengikat. Pasca pentupan pos lintas batas di Sei Pancang berdampak signifikan terhadap warga perbatasan yang ingin melintas. Hal ini dapat memunculkan banyaknya pelangggar batas illegal. Namun pada pelaksanaanya dalam upaya mengurangi pelanggaran tapal batas dikawasan perbatasan pemerintah dihadapkan oleh banyak faktor yang dapat mempengaruhi penegakan hukum, faktor undang-undang, faktor penegak hukum, faktor sarana dan fasilitas, faktor kebudayaan dan masyarakat

Kata Kunci : Pemerintah, Penegakan Hukum, Wilayah Perbatasan

\section{PENDAHULUAN}

Berdasarkan Pasal 1 ayat (2) UUD NRI Tahun 1945 menyatakan bahwa: "Kedaulatan ada ditangan rakyat dan dilakukan menurut Undang-Undang Dasar ini”. Salah satu kedaulatan yang mendasar adalah pengawasan terhadap pengelolaan dan tanggung jawab mengenai keuangan Negara. Tugas pelaksanaan kedaulatan ini sebagaimana yang tertuang dalam UUD NRI Tahun 1945 diberikan kepada Badan Pemeriksa Keuangan (BPK). Pembentuk menyadari bahwa untuk memeriksa cara pemerintah menggunakan uang belanja yang disetujui oleh rakyat melalui DPR diperlukan suatu Negara yang dapat secara objektif menjalankan tugasnya.

Pengelolaan wilayah perbatasan, khususnya di perbatasan maritim, pada akhirakhir ini semakin menjadi perhatian dan pembicaraan berbagai kalangan, baik pemerintahan, elit politik, media massa, masyarakat maupun dunia usaha, Pemerintah, baik Pusat maupun Daerah, telah menerapkan berbagai kebijakan dan peraturan terkait pengelolaan perbatasan, baik prasarana maupun kesejahteraan masyarakat di wilayah perbatasan. Menyadari bahwa wilayah perbatasan merupakan wilayah rawan konflik antar negara maupun dunia internasional, maka kebijakan pembangunan wilayah perbatasan harus direncanakan dan dilaksanakan secara terpadu dan komprehensif, terkait kepentingan kesejahteraan dan kepentingan pertahanan keamanan dengan tidak meninggalkan kepentingan kelestarian lingkungan hidup. ${ }^{1}$

Hal ini dikarenakan implementasi pembangunan yang dilaksanakan sampai saat ini, belum menunjukkan hasil yang diharapkan. Akibatnya berbagai bentuk

1 Purnomo Yusgiantoro, Pengelolaan Perbatasan Mengsinergikan Keamanan dan Kesejahterahan, (Tabloid Diplomasi, 15 Februari-14 Maret 2013). h. 7-8. 
dan jenis ancaman, baik militer maupun nirmiliter ${ }^{2}$, pelanggaran wilayah oleh kapal-kapal militer ataupun sipil dan berbagai bentuk kegiatan illegal yang terjadi, begitu mudah dilakukan dengan menggunakan wilayah perbatasan sebagai pintu ke luar negeri. Dengan kata lain, wilayah di halaman depan kita dengan mudah dapat dimasuki oleh berbagai bentuk dan jenis ancaman, baik yang terkait dengan aspek geografi, demografi, sumber kekayaan alam, geologi, Politik, ekonomi, sosial dan budaya serta pertahanan dan keamanan. ${ }^{3}$

Peranan penting dari wilayah negara dalam hukum internasional tercermin dalam prinsip penghormatan terhadap integritas kewilayahan (territorial integrity) yang dimuat dalam pelbagai instrumen internasional. misalnya dalam bentuk larangan untuk melakukan intervensi terhadap masalah-masalah internal dari suatu negara. Meskipun demikian, sebagai akibat dari perkembangan teknologi dan ekonomi dewasa ini, dalam hubungan antar negara tampak adanya kecenderungan untuk mengurangi peran eksklusif dari wilayah negara, khususnya dalam masalah-masalah yang berkaitan hak asasi manusia dan hak untuk menentukan nasib sendiri (self determination). Namun, hingga saat ini kedaulatan teritorial tetap merupakan suatu konsep penting dalam hukum internasional dan telah melahirkan berbagai ketentuan hukum tentang perolehan dan hilangnya wilayah negara. ${ }^{4}$

Fenomena yang terjadi di beberapa daerah di Indonesia dalam hal gangguan pertahanan dan keamanan merupakan cerminan pemegang kebijakan yang kurang mampu mengatasi permasalahan internal yang terjadi di daerahnya. Kesenjangan ekonomi di dalam struktur masyarakat akan memunculkan kerawanan sosial, sehingga tidak jarang ditemui dalam sejarah Indonesia, ketika perekonomian nasional sedang terpuruk, maka yang terjadi adalah munculnya kecemburuan sosial yang diakibatkan perbedaan antara si kaya dan si miskin yang begitu mencolok. ${ }^{5}$

Sama hal dengan pengelolaan wilayah perbatasan yang sering kita temui, akibat pemegang kekuasaan yang selalu mengkesampingkan hal tersebut. Padahal wilayah perbatasan merupakan halaman depan negara Indonesia namun sangat

\footnotetext{
${ }^{2}$ Ancaman Nirmiliter adalah ancaman yang menggunakan factor-faktor nirmiliter yang dinilai mempunyai kemampuan yang membahayakan kedaulatan negara, keutuhan wilayah negara dan keselamatan segenap bangsa. Ancaman ini dapat berdimensi ideology, ekonomi, politik, social, budaya, teknologi dan informasi.

3 Ibid.,

${ }^{4}$ Mochtar Kusumaatmadja, Pengantar Hukum Internasional, (Bandung: Alumni, 2012) h. 162.

5 Asren Nasution, Pertahanan Negara Di Wilayah Pesisir Perspektif Pengembangan Wilayah, (Jakarta: Prenada, 2011). h. 4.

56
} 
kurang sekali tersentuh pembangunan di wilayah tersebut sehingga banyak masyarakat di wilayah perbatasan yang menggantungkan hidupnya di negara tetangga.

Misalnya dalam hal pemberian identitas, Menteri Desa, Pembangunan Daerah Tertinggal dan Transmigrasi (Mendes), di era pemerintahan Presiden Susilo Bambang Yudhoyono (SBY) Marwan Jafar mengatakan pemberian identitas penduduk kepada warga desa di sejumlah wilayah perbatasan Indonesia oleh Malaysia adalah modus yang harus disikapi dan perlu diawasi. Dalam wawancaranya di media Tempo Marwan Jafar mengatakan : ${ }^{6}$

"Bayangkan jika semua penduduk desa Indonesia mempunyai identitas Malaysia. desa itu ibarat desa siluman."

Hal ini menegaskan kurangnya perhatian pemerintah selaku pemegang kekuasaan dalam memperhatikan wilayah sendiri. Selain daripada itu masalah perbatasan bukan hanya menyangkut masalah pemberian identitas namun mulai dari pergeseran patok hingga masalah pendistribusian bahan pangan. Kurangnya perhatian pemerintah mengakibatkan banyak patok-patok di wilayah perbatasan mengalami kerusakan bahkan ada yang mengalami pergeseran yang sangat jauh sampai ada patok yang sengaja dihilangkan dari tempatnya.

Permasalahan pertahanan batas selalu dijaga ketat supaya tak ada tangantangan usil yang menggeser batas wilayah. Namun, kenyataannya Indonesia masih disebut lalai menjaga pertahanan batas-batas wilayah, baru-baru ini, Komandan Kodim 0911/Nunukan, Kalimantan Utara, Letkol Inf Putra Widiastawa menyatakan ada 12 patok perbatasan Indonesia-Malaysia yang hilang di Desa Sekaduyan Taka Kecamatan Seimenggaris Kabupaten Nunukan. Kasus hilangnya tapal batas itu pun segera mencuat karena menyangkut yurisdiksi. ${ }^{7}$

Menurut Komandan Kodim 0911/Nunukan, Kalimantan Utara, Letkol Inf Putra Widiastawa, ada 12 patok perbatasan Indonesia-Malaysia yang hilang di Desa Sekaduyan Taka Kecamatan Seimenggaris Kabupaten Nunukan. Dalam klarifikasinya melalui via pesawat telepon mangatakan $:^{8}$

"Sesuai hasil pengecekan kami di lokasi, terdapat 12 patok perbatasan yang hilang."

6 Odelia Sinaga, Modus Malaysia Kuasai Desa di Perbatasan Indonesia, https://m.tempo.co/read/news/2014/11/17/078622324/modus-malaysia-kuasai-desa-diperbatasan-indonesia, diakses pada tanggal 15 April 2019 pada pukul 01.00

7 Eda Ervina, Cerita Hilangnya Patok Batas Indonesia-Malaysia di Nunukan, http://www.merdeka.com/peristiwa/cerita-hilangnya-patok-batas-indonesia-malaysia-di nunukan/kapolda-kaltim-akan-tinjau-pos-perbatasan.html, diakses pada tanggal 15 April 2019 pada pukul 01.00

8 Ibid., 
Putra mengungkapkan selain patok yang hilang, terdapat 16 patok perbatasan kedua negara di daerah itu yang ditemukan rusak, Putra mengaku khawatir hilangnya patok batas antara Indonesia dan Malaysia akan menimbulkan gesekan antara dua negara, mengingat hubungan dua negara sempat naik dan turun. ${ }^{9}$

Banyaknya permasalahan yang timbul di daerah perbatasan di Indonesia. sudah seharusnya pemerintah harus mengkaji ulang dalam memetakan wilayah-wilayah indonesia yang tengah bermasalah. Dan diperlukan sikap politik pemerintah Indonesia dalam menegaskan wilayahnya. Hal ini dapat menyulitkan pemerintah disamping banyaknya masalah tumpang tinding dalam perbatasan di negara tetangga, kondisi geografis Indonesia yang memungkinkan hal ini terjadi. Tugas pemerintah sebagai negosiator sangat diperlukan agar dapatkan menegaskan wilayah perbatasan yang saling klaim satu sama lain. Dari latar belakang diatas maka dapat dirumuskan permasalahan sebagai berikut : Bagaimana mengurangi terjadinya pelanggaran tapal batas didaerah perbatasan Indonesia dan Malaysia.

\section{METODE PENELITIAN}

Penelitian atas permasalahan di atas adalah merupakan penelitian hukum empiris normatif yang di maksudkan untuk mengidentifikasi konsep, gagasan dan asas-asas hukum dalam menelaah dan mengkaji upaya pemerintah dalam mengurangi pelanggaran tapal batas Indonesia-Malaysia (Studi kasus Kabupaten Nunukan). Penelitian ini dilakukan Kabupaten Nunukan dengan pertimbangan data yang diperlukan berada di lokasi tersebut. 1. Kantor Pemerintahan Daerah Kabupaten Nunukan. 2. Komando Distrik 0911 Kab. Nunukan. 3. Departemen Keimigrasian Kab. Nunukan. 4. Komando Angkatan Laut Kab. Nunukan

Tipe dalam penelitian ini merupakan tipe penelitian Normatif-Empiris yaitu meneliti aturan-aturan yang ada, aturan Hukum Internasional maupun aturan Hukum Nasional terkait objek kajian yang saya teliti serta menganalisis aturan tersebut sehingga dapat memberikan solusi dalam menyelesaikan masalah yang terjadi saat ini. Dalam hal ini disamping penelitian Empiris. penelitian ini juga mengambil pendekatan undang-undang yang dimana penelitian ini meneliti produk hukum yang dikeluarkan selain daripada itu pendekatan politis digunakan guna mempertimbangkan kebijakan elit politik serta partisipasi masyarakat dalam pembentukkan produk hukum yang di buat oleh pemerintah.

Populasi dalam penelitian ini merupakan pihak-pihak yang terkait dalam instansi tempat saya meneliti yaitu : Dandim 0911 Kab. Nunukan. Kabag Perbatasan Kab.Nunukan dan Departemen Imigrasi Republik Indonesia dari populasi tersebut ditetapkan atau dipilih secara acak. Dalam hal ini sampel yang

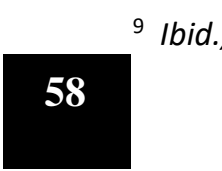


saya ambil dari kalangan warga yang bermukim ada diwilayah perbatsan Indonesia. selain daripada itu penulis juga mengambil 4 narasumber dari instansi yang menjadi tempat penelitian saya. Dalam mengumpulkan data yang dibutuhkan diperlukan teknik pengumpulan data sebagai berikut: A). Wawancara (Interview) : teknik pengumpulan data yang didapatkan secara langsung dari narasumber yang terkait dengan instansi tersebut dengan menggunakan Pedoman Wawancara.B). Dokumentasi : teknik pengumpulan data yang mengumpulkan dokumen-dokumen penting instansi terkait dengan objek kajian yang diangkat serta menganalisis dokumen tersebut dengan mengkorelasikannya dengan permasalahan serta mengaitkannya dengan teori hukum itu sendiri.

Data yang diperoleh atau dikumpulkan dalam penelitian ini merupakan data yang sifatnya kualitatif maka analisis data yang digunakan adalah analisis kualitatif. dimana proses pengolahan datanya yakni setelah data tersebut terkumpul dan dianggap telah cukup. data tersebut diolah dan dianalisis secara deskriptif yaitu dengan berlandaskan kepada dasar-dasar pengetahuan umum kemudian meneliti persoalan yang bersifat khusus. Dari adanya analisis inilah kemudian ditarik suatu jawaban dari permasalahan penelitian tersebut.

\section{PEMBAHASAN}

\section{A. Cara Pemerintah Dalam Mengurangi Pelanggaran di Tapal Batas Indonesia dan Malaysia}

Dinamika kondisi politik perbatasan diwarnai oleh permasalahan belum tuntasnya kesepakatan garis batas wilayah negara kesatuan republik Indonesia dengan wilayah negara tetangga, baik batas darat maupun batas laut. Kondisi ini memunculkan isu-isu strategis yang menyentuh masalah kedaulatan negara, ketahanan nasional, pertahanan, keamanan, lepasnya pulau-pulau Indonesia (Sipadan dan Ligitan), TKI illegal, illegal fishing, penyelundupan, kesenjangan di bidang ekonomi, sosial dan budaya. Karena itu salah satu tujuan program pembangunan wilayah perbatasan yang diformulasikan berdasarkan RPJM 20152019, adalah "membangun Indonesia dari pinggiran dengan memperkuat daerahdaerah dan desa dalam kerangka negara kesatuan". ${ }^{10}$

Keamanan nasional pada hakikatnya adalah kondisi dinamis kedamaian dan ketenteraman bangsa dan Negara, yang merupakan hasil integrasi dan interaksi faktor-faktor dinamis yang memungkinkan seluruh rakyat berkembang sesuai kemampuan dan tuntutan hidup masing-masing dalam kehidupan masyarakat

${ }^{10}$ Muhammad Syafei,: "Pengaturan Pengelolaan Kawasan Perbatasan Kalimantan BaratSarawak Malaysia”. (Makassar: Disertasi Universitas Hasanuddin, 2012). h. 271.

59 
yang berdasarkan pancasila dan UUD $1945 .{ }^{11}$ Keamanan nasional merupakan hal terpenting dalam menjaga kawasan suatu Negara, di sisi lain Indonesia merupakan Negara kepulauan yang memiliki batas dengan negara tetangga baik laut maupun darat.

Isu keamanan baik dalam pengertian tradisional (militer) mapun persoalan keamanan non-tradisional. Isu keamanan militer terutama terjadi di wilayah perbatasan Indonesia-Papua Nugini dan Indonesia-Timor Leste. Namun seiring dengan meningkatnya signifikansi aktor non negara, masalah non tradisional yang memanfaatkan wilayah perbatasan juga semakin meningkat. Penyelundupan manusia, penyelundupan barang-barang komoditas, pembalakan liar, peyelundupan obat-obat terlarang dan yang paling mengkhawatirkan ancaman terorisme. $^{12}$

Terkait dengan wilayah perbatasan Indonesia telah memiliki paling tidak 23 peraturan perundangan yang terkait penetuan batas dan pengembangan kawasan perbatasan. Namun demikian upaya untuk menegakan aturan perundangan itu masih belum menunjukkan hasil. Salah satu faktor yang menyulitkan upaya implementasi peraturan perundangan tersebut adalah faktor kelembagaan. Ketidakjelasan otoritas mana yang melaksanakan tugas manajemen wilayah perbatasan. Kelembagaan yang ada masih bersifat ad hoc, koordinatif secara sektoral dan belum terintegrasi secara khusus dalam satu lembaga tertentu. Oleh karenanya penanganan masalah perbatasan cenderung bersifat parsial dan tidak komprehensif gagal mengatasi dinamika perbatasan yang muncul di wilayah perbatasan. ${ }^{13}$ Sebagai respon atas hal itu, pada tahun 2010 dibentuklah Badan Nasional Pengelola Perbatasan (BNPP) atas dasar Peraturan Presiden no 12 tahun 2010, sebagai lembaga yang mengkoordinir segenap agenda dan upaya yang terkait dengan pengelolaan perbatasan. ${ }^{14}$

Perbatasan merupakan perwujudan dari kedaulatan territorial. Sebagaimana makna perbatasan yaitu suatu daerah atau jalur pemisah antara unit-unit politik negara, maka perbatasan negara mengandung komponen paling sedikit dua Negara yang berbatasan, dengan demikian, juga komponen rakyat dari Negara

11 Suryanto Suryokusumo dkk, Konsep Sistem Pertahanan Nonmiliter: Suatu Sistem Pertahanan Komplemen Sistem Pertahanan Militer dalam Pertahanan Rakyat Semesta, Yayasan Pustaka Obor Indonesia, (Jakarta, 2016) h.82-83.

12 Aryanta Nugraha, Institusionalisasi Pengelolaan Wilayah Perbatasan di Indonesia", dalam Ludiro Madu (ed.), Mengelola Perbatasan Di Dunia Tanpa Batas, (Yogyakarta: Graha Ilmu, 2010). h. 37.

13 Ibid., h. 38

14 Mita Noveria et.al, Kedaulatan Indonesia Di Wilayah Perbatasan Perspektif Multidimensi, (Jakarta: Yayasan Pustaka Obor, 2017). h. 106.

60 
yang berbatasan. Maka ketika berbicara aktor perbatasan, secara langsung kita akan mengatakan paling sedikit ada empat stakeholder yang terlibat, yaitu pemerintah Negara A di satu sisi perbatasan, pemerintah Negara B di sisi perbatasan yang lain, rakyat yang tinggal di daerah perbatasan di Negara A, rakyat yang tinggal di daerah perbatasan di Negara B. ${ }^{15}$

\section{B. Faktor-Faktor Yang Mengurangi Pelanggaran Tapal Batas yang ada di Perbatasan Indonesia}

\section{Faktor Undang-Undang}

Wilayah perbatasan RI-Malaysia merupakan salah satu garis pertahanan NKRI. Sebagai kawasan strategis, wilayah perbatasan ini memiliki potensi kerawanan ancaman keamanan baik militer dan non militer. Oleh karena itu, diperlukan upaya termasuk seperangkat kebijakan untuk menjaga keutuhan Negara di wilayah tersebut. ${ }^{16}$

Dalam mengkaji konteks wilayah perbatasan tidak bisa lepas dengan strategi pertahanan nasional. Hal ini mengacu pada aturan yang terkait dengan kewenangan pemerintah pusat dalam undang-undang no 23 tahun 2014 tentang Pemerintahan Daerah yang secara jelas menyatakan ada enam kewenangan mutlak pemerintah pusat yaitu: Politik luar negeri, pertahanan, keamanan, agama, yustisi, moneter dan fiskal nasional. Dengan aturan tersebut pemerintah daerah di perbatasan RI-Malaysia tidak diberi kewenangan dalam mengelola pertahanan diwilayah perbatasan. Hal ini menjadi kewenangan pemerintah pusat.

Dilihat dari aspek legal formal, pemerintah telah mengeluarkan sejumlah peraturan perundang-undangan baru terkait perbatasan. Menurut Moeldoko, peraturan perundangan yang berhasil di identifikasi antara lain adalah lima undang-undang (UU), satu peraturan pemerintah (PP) dan tiga peraturan presiden (Perpres). Kelima undang-undang tersebut yaitu: ${ }^{17}$

1. UU no 17 tahun 2007 tentang Rencana Pembangunan Jangka Panjang Nasional (RPJPN) tahun 2005-2025.

2. UU no 43 tahun 2008 tentang Wilayah Negara.

3. UU no 26 tahun 2007 tentang Penataan Ruang.

15 Wahyuni Kartikasari, Mengurai Pengelolaan Perbatasan di Wilayah-wilayah Perbatasan Indonesia“, dalam Ludiro Madu (ed.), Mengelola Perbatasan Di Dunia Tanpa Batas, (Yogyakarta: Graha Ilmu, 2010). h. 107.

16 Mita Noveria et.al, Kedaulatan Indonesia Di Wilayah Perbatasan Perspektif Multidimensi, (Jakarta: Yayasan Pustaka Obor, 2017). h. 65-66.

17 Ibid., h. 67. 
4. UU no 27 tahun 2007 tentang Pengelolaan Wilayah Pesisir dan PulauPulau Kecil.

5. UU no 23 tahun 2014 tentang Pemerintahan Daerah.

Sementara itu peraturan pemerintah yang memiliki keterkaian erat dengan pengelolaan perbatasan adalah peraturan pemerintah no 26 tahun 2008 tentang Rencana Tata Ruang Wilayah Nasional. Sedangkan peraturan presiden terkait dengan pengelolaan perbatasan:

1. Peraturan presiden no 2 tahun 2015 tentang Rencana Jangka Menengah Nasional (RPJMN) tahun 2015-2019.

2. Peraturan presiden no 78 tahun 2005 tentang Pengelolaan Pulau-pulau Kecil Terluar.

3. Peraturan presiden no 12 tahun 2010 tentang Badan Nasional Pengelola Perbatasan.

Hal ini sangat terlihat jelas bahwa tekad pemerintah dalam membangun wilayah perbatasan begitu kuat dengan melahirkan berbagai produk hukum guna mempercepat pembangunan wilayah perbatasan disatu sisi juga ini merupakan nawacita ketiga presiden Joko Widodo dalam membangun Indonesia melalui pinggiran.

Dalam hal aspek pengamanan wilayah perbatasan, UU no 43 tahun 2008 tentang Wilayah Negara telah memberikan pemerintah kewenangan dalam mengelola wilayah perbatasan. Sebagaimana yang tercantum dalam pasal 10 , kewenangan pemerintah antara lain:

a. menetapkan kebijakan pengelolaan dan pemanfaatan Wilayah Negara dan Kawasan Perbatasan;

b. mengadakan perundingan dengan negara lain mengenai penetapan Batas Wilayah Negara sesuai dengan ketentuan peraturan perundangundangan dan hukum internasional;

c. membangun atau membuat tanda Batas Wilayah Negara;

d. melakukan pendataan dan pemberian nama pulau dan kepulauan serta unsur geografis lainnya;

e. memberikan izin kepada penerbangan internasional untuk melintasi wilayah udara teritorial pada jalur yang telah ditentukan dalam peraturan perundang-undangan;

f.memberikan izin lintas damai kepada kapal-kapal asing untuk melintasi laut teritorial dan perairan kepulauan pada jalur yang telah ditentukan dalam peraturan perundang-undangan;

g. melaksanakan pengawasan di zona tambahan yang diperlukan untuk mencegah pelanggaran dan menghukum pelanggar peraturan perundang- 
undangan di bidang bea cukai, fiskal, imigrasi, atau saniter di dalam Wilayah Negara atau laut teritorial;

h. menetapkan wilayah udara yang dilarang dilintasi oleh penerbangan internasional untuk pertahanan dan keamanan;

i. membuat dan memperbarui peta Wilayah Negara dan menyampaikannya kepada Dewan Perwakilan Rakyat sekurang-kurangnya setiap 5 (lima) tahun sekali; dan

j. menjaga keutuhan, kedaulatan, dan keamanan Wilayah Negara serta Kawasan Perbatasan.

Dengan tugas yang diberikan pemerintah dalam pasal 10 tersebut secara tegas pemerintah telah dipandang perlu untuk memelihara dan mempertahankan eksistensi Negara melalui kekuatan politik, ekonomi, pertahanan, keamanan, dan hubungan diplomasi. Biasanya konsep keamanan nasional menekankan pada kemampuan pemerintah untuk melindungi integritas wilayah negara, termasuk di wilayah perbatasan Indonesia dengan Malaysia sepanjang provinsi Kalimantan utara dan Kalimantan barat, dari ancaman baik yang datang dari luar maupun ancaman dari dalam.

Dalam segi regulasi pemerintah sudah cukup baik dalam membuat sebuah badan yang fokus dalam mengurusi terkait perbatasan BNPP (Badan Nasional Pengelolaan Perbatasan) sebagai representasi dari pemerintah pusat, badan yang mempunyai tugas sebagai badan yang menetapkan kebijakan program pembangunan perbatasan, menetapkan rencana kebutuhan anggaran, mengoordinasikan pelaksanaan, dan melaksanakan evaluasi dan pengawasan terhadap pengelolaan Batas Wilayah Negara dan Kawasan Perbatasan. Hal ini sangatlah membantu kerja pemerintah dalam mengelola perbatasan.

Namun sejak adanya perubahan dari pemerintah daerah, badan nasional pengelola perbatasan menjadi bagian wilayah perbatasan ruang lingkup kerja bagian perbatasan sangatlah sempit hal cenderung kerja di bagian sekretariat sebaliknya ketika menjadi badan fokusnya ke wilayah perbatasan, adanya kebijakan ini membuat proses pembangunan wilayah perbatasan menjadi terhambat. Kami berharap pemerintah pusat memfasilitasi kami dari badan menjadi dinas yang terkait dan fokus mengurusi wilayah perbatasan ada 27 kabupaten telah menyurati sekrertariat Negara terkait hal tersebut, ujar Muhammad Effendi., S.IP (Kepala Bagian Wilayah Perbatasan Kabupaten Nunukan). ${ }^{18}$

18 Wawancara dengan Muhammad Efendi, pada tanggal 11 september 2017 di kantor pemerintahan Kab. Nunukan

63 


\section{Faktor Penegak Hukum}

Pada dasarnya timbulnya perhatian orang terhadap telaah hukum secara sosiologis disebabkan oleh adanya perbedaan antara ketentuan-ketentuan hukum di satu pihak dan beroperasinya atau dioperasikannya ketentuanketentuan tersebut di pihak lain. Pada umumnya, tinjauan yang mencoba untuk mengungkapkan sebab-sebab bagi timbulnya minat telaah hukum secara sosiologis di dalam suatu Negara memang menunjuk pada perubahanperubahan sosial yang berlangsung di dalam wilayah itu. Keadaan tersebut dapat dijelaskan sebagai berikut. ${ }^{19}$

Masalah yang diatur ini dapat dipecah dalam aspek kuantitas, sifat-sifat hubungan dan bidang. Setiap masalah itu dapat dikenali dalam berbagai aspeknya tersebut. Setiap peraturan hukum seolah-olah sudah dibuat pas (geared) pada aspek-aspek masalah yang diaturnya. Ketidaksesuaian disini akan timbul apabila suatu peraturan mulai tidak pas lagi pada masalah yang diaturnya. Keadaan seperti ini dapat juga di jumpai pada lembaga-lembaga hukum. ${ }^{20}$ Hal ini turut andil para aparat penegak hukum yang menjalankan peraturan tersebut. Adanya perbedaan dalam melaksanakan suatu peraturan dikarenakan salah satu faktor mendasar yaitu dari segi kesejahteraan yang rendah para aparat penegak hukum serta masyarakat yang berperan dalam proses penegakan hukum.

Dalam proses bekerjanya aparatur penegak hukum itu, terdapat tiga elemen penting yang mempengaruhi, yaitu: (i) institusi penegak hukum beserta berbagai perangkat sarana dan prasarana pendukung dan mekanisme kerja kelembagaannya; (ii) budaya kerja yang terkait dengan aparatnya, termasuk mengenai kesejahteraan aparatnya, dan (iii) perangkat peraturan yang mendukung baik kinerja kelembagaannya maupun yang mengatur materi hukum yang dijadikan standar kerja, baik hukum materielnya maupun hukum acaranya. Upaya penegakan hukum secara sistemik haruslah memperhatikan ketiga aspek itu secara simultan, sehingga proses penegakan hukum dan keadilan itu sendiri secara internal dapat diwujudkan secara nyata. ${ }^{21}$

Selain tingkat kesejahteraan yang rendah dan keterisolasian terdapat pula kesenjangan pembangunan perbatasan yang sangat jauh berbeda dengan negara tetangga. Di sisi lain yang menjadi kendala para penegak hukum yang berada di wilayah perbatasan masih adanya beberapa peraturan yang dimana peraturan tersebut sudah dianggap tidak relevan lagi dengan perkembangan zaman, salah satunya terkait Border Trade Agreement Indonesia dengan Malaysia tahun 1970 dijelaskan satu orang hanya bisa membawa barang dari Malaysia ke Indonesia ataupun sebaliknya sebesar 600 Ringgit Malaysia kalau di kurs

19 Satjipto Rahardjo, Pemanfaatan Ilmu-ilmu Sosial Bagi Pengembangan Ilmu Hukum, (Jakarta: Genta Publishing, 2010). h. 67.

${ }^{20}$ Ibid., h. 68.

21 Jimly Asshiddiqie, 2010, Penegakan Hukum, http://www.jimly.com/makalah/namafile L56/PenegakanHukum.pdf, diakses pada tanggal 02 september 2017

\section{4}


rupiah kan sekitar Rp. 2.000.000,- (Dua Juta Rupiah), diluar dari nominal ditetapkan sudah terkena pajak. Hal ini lah yang menjadikan para penegak hukum yang ada disana seperti melakukan pembiaran dan menganggap peristiwa ini sebagai kearifan lokal. Keberadaan pemerintah di wilayah perbatasan belum dapat menjangkau hal tersebut. Tutur Letnan Kolonel Kav Valian Wicaksono (Komandan Distrik Militer Kabupaten Nunukan). ${ }^{22}$

Penegak hukum di wilayah perbatasan dihadapkan oleh posisi hukum adat dengan hukum positif Indonesia yang dimana posisi hukum adat diatas hukum positif seperti contoh ada sengketa pengelolaan tanah di daerah sungai semantipal antara masyarakat adat yang tinggal diwilayah Malaysia dan yang tinggal di wilayah Indonesia mengajukan masalah tersebut melalui dua hukum positif masing-masing telah namun, diselesaikan oleh kedua hukum positif antar kedua negara namun masyarakat adat yang bersengketa telah didamaikan namun hukum adat didaerah tersebut masih menerapkan sanksi denda oleh kedua bela pihak seolah-olah hukum adat tidak mau tunduk dengan hukum nasional, hal ini juga menjadi salah satu tantangan berat para penegak hukum. Seharusnya dibutuhkan sosialisasi antara pemuka adat serta penegak hukum terkait kedudukan hukum nasional dan hukum adat khususnya masyarakat perbatasan agar tidak merugikan satu sama lain ujar Amiruddin (Kepala bagian Hukum Kabupaten Nunukan). ${ }^{23}$

Dalam hal masalah perbatasan para penegak hukum dihadapkan dengan masalah kelembagaan itu sendiri. Kurang terintegrasinya dan terkoordinasinya setiap lembaga terkait seringkali menyebabkan sasaran hasil pengelolaan perbatasan menjadi tidak optimal. Oleh karena itu, perlu adanya sebuah struktur kelembagaan yang dapat menjembatani dan mensinergikan seluruh potensi lembaga terkait agar tercipta sebuah pelaksanaan pengelolaan perbatasan yang terintegrasi, fokus dan efisien. Kelembagaan tersebut nantinya juga memiliki peran yang sangat signifikan di dalam penyusunan kebijakan, program, kegiatan, serta pendanaan pengelolaan perbatasan di seluruh Indonesia. ${ }^{24}$

\section{Faktor Sarana dan Fasilitas}

Tanpa adanya sarana atau fasilitas tertentu, maka tidak mungkin penegakan hukum akan berlangsung dengan lancar. Sarana atau fasilitas tersebut, antara lain, mencakup tenaga manusia yang berpendidikan dan terampil, organisasi yang baik, peralatan yang memadai, keuangan yang cukup, dan seterusnya.

\footnotetext{
${ }^{22}$ Wawancara dengan letnan Kolonel Kav Valian Wicaksono, pada tanggal 11 september 2017 di kantor Kodim 0911 Kab.Nunukan.

${ }^{23}$ Wawancara dengan Amiruddin., SH, pada tanggal 8 september 2017 di kantor Pemerintahan Kab.Nunukan.
}

24 Sobar Sutisna, Boundary Making Theory dan Pengelolaan Perbatasan di Indonesia, dalam Ludiro Madu (ed.), Mengelola Perbatasan Di Dunia Tanpa Batas (Yogyakarta: Graha Ilmu, 2010). h. 20.

65 
Kalau hal-hal itu tidak terpenuhi, maka mustahil penegakan hukum akan mencapai tujuannya. ${ }^{25}$

Selain tingkat kesejahteraan masyarakat di wilayah perbatasan yang patut diperhatikan, sarana dan fasilitas umum harus juga diperhatikan guna menunjang proses penegakan hukum diwilayah perbatasan. kondisi inilah yang menjadi tantangan berat para penegak hukum.

Di daerah perbatasan kesenjangan sosial yang sangat bertolak belakang yang ada di seberang pulau. Iklim sama, sumber daya alam sama, cuaca juga sama namun pembangunan sangatlah lambat. Di daerah krayan apabila anda tiba-tiba mendapatkan jalan yang mulus jangan pikir itu indonesia pasti malaysia, tapi apabila anda telah melihat wilayah yang berbatu hutan-hutan dan jalan lumpur sudah pasti Indonesia. Ada hal yang menarik ketika saya melihat dua tentara antara Indonesia dengan Malaysia disatu sisi, di negara malaysia yang dimana notabene satuan tugas pengamanan perbatasan (Satgas Pamtas) nya di layani oleh pemerintahannya sendiri bak seorang raja sedangkan tentara Indonesia sangat minim akan fasilitas. ujar Serfianus S.IP (Kepala Bappeda Kabupaten Nunukan). ${ }^{26}$

Pulau Sebatik memiliki potensi kekayaan terutama pertanian-perkebunan dan perikanan. Komoditas yang menjadi andalan bagi warga adalah pisang, sawit, dan kelapa yang dijual ke Tawau, Malaysia. Namun demikian, masyarakat Sebatik menghadapi keterbatasan air bersih. Mereka mengandalkan air hujan untuk memenuhi kebutuhan harian. Padahal, air adalah kebutuhan dasar bagi keberlangsungan hidup masyarakat. Infrastruktur transportasi laut secara umum sudah cukup baik. Ada kapal motor yang melayani rute Sebatik ke Tarakan. Ada pula kapal-kapal cepat milik warga yang melayani rute Sebatik ke Nunukan. Adapun untuk infrastruktur darat, sebagian besar jalan sudah beraspal, walaupun di beberapa titik kondisinya memprihatinkan akibat jalan longsor yang belum diperbaiki. Untuk infrastruktur pendidikan dan kesehatan, terdapat fasilitas sekolah dari SD sampai SMA serta puskesmas dan posyandu di kecamatan-kecamatan pulau ini. Namun demikian, belum tersedia rumah sakit untuk rawat inap. Selama ini, warga yang butuh dirujuk harus menyeberang ke Nunukan yang membutuhkan waktu dan biaya yang lebih banyak. $^{27}$

Modal sumber daya manusia, warga Sebatik berusia 15 tahun ke atas yang bekerja paling banyak hanya lulusan SD (37,52\%). Hal ini dipengaruhi oleh terbatasnya sarana prasarana pendidikan tingkat menengah seperti ketersediaan

${ }^{25}$ Soerjono Soekanto, Faktor-faktor Yang Mempengaruhi Penegakan Hukum, (Jakarta: Rajawali Pers, 2013). h. 37.

26 Wawancara dengan Serfianus, tanggal 8 september 2017 dalam forum group discussion Pimpinan Daerah Muhammadiyah Kab.Nunukan.

27 Sandy Nur Ikfal Raharjo, et.al, Strategi Peningkatan Kerja Sama Lintas Batas (Border Crossing Agreement) Indonesia Malaysia, (Jakarta: Lembaga Ilmu Pengetahuan Indonesia, 2017). h. 1. 
sekolah dan tenaga pengajar, serta kekurangmampuan orang tua untuk menyekolahkan anaknya ke jenjang pendidikan yang lebih tinggi. modal ekonomi dan keuangan, secara umum masyarakat Sebatik bermata pencaharian sebagai petani/pekebun, nelayan, dan pedagang. Namun dalam struktur ekonomi Kabupaten Nunukan, pertanian mulai dikalahkan oleh pertambangan sebagai sektor yang paling berkontribusi terhadap Produk Domestik Regional Bruto (PDRB), yaitu 55,07\% pada tahun 2014, sementara sektor pertanian hanya 20,10\%. Jadi, walaupun secara umum PDRB perkapita di Nunukan, termasuk Sebatik, cukup besar yaitu Rp 93.045.780 perkapita/pertahun atau Rp 7.753.815 perkapita/perbulan, tetapi untuk mayoritas masyarakat yang bekerja di sektor pertanian (termasuk perikanan) hanya Rp 18.705 .300 perkapita/pertahun atau Rp 1.558 .775 perkapita/perbulan. Angka ini lebih kecil dari rata-rata kebutuhan hidup layak di Nunukan tahun 2014, yaitu sebesar Rp 2.189.365. ${ }^{28}$

Pemerintah pusat memberikan perhatian yang besar terhadap Pulau Sebatik. Mereka mengalokasikan anggaran sebesar 1,08 triliun untuk pembangunan di wilayah perbatasan Kabupaten Nunukan pada tahun 2015. Kemudian, mengingat Sebatik adalah wilayah perbatasan yang rawan terhadap pelanggaran kedaulatan, di Sebatik terdapat satuan tugas pengamanan perbatasan (satgas pamtas) TNI AD maupun Pos AL. Namun demikian, jumlah personil yang terbatas dan kurangnya sarana operasi membuat pengamanan wilayah perbatasan menjadi kurang optimal. Padahal, wilayah ini dekat dengan Perairan Tawi-Tawi di Filipina Selatan yang merupakan wilayah konflik separatis dan rawan perompakan. Selain itu, masyarakat Sebatik juga menghadapi tantangan eksternal yaitu maraknya penyelundupan barang terlarang (narkoba) dari Malaysia. Kondisi di atas menggambarkan kerentanan (vulnerability) masyarakat pulau-pulau kecil terluar. Dalam rangka mengatasi masalah diatas, pemerintah Indonesia sendiri mengalami berbagai kendala. Pertama, pemerintah tidak dapat menutup kawasan perbatasan dari dunia luar, karena fenomena globalisasi memang sudah menjangkau kawasan perbatasan Indonesia. Kedua, pemerintah Indonesia juga memiliki keterbatasan kemampuan untuk dapat mengatasi semua persoalan di atas secara mandiri. Kondisi ini menjadi dasar bagi perlunya solusi alternatif untuk meningkatkan ketahanan sosial masyarakat pulau-pulau kecil terluar. ${ }^{29}$

Pembangunan yang tidak merata mengakibatkan banyaknya desa-desa diwilayah perbatasan memilih mengantungkan hidupnya di Negara Malaysia, selama ini pemerintah pusat menganggap bahwa sebatik merupakan wilayah perbatasan semata. Sehingga mengakibatkan banyaknya warga Negara Indonesia di wilayah perbatasan mengambil segala cara agar mendapatkan perhatian dari Negara tetangga.

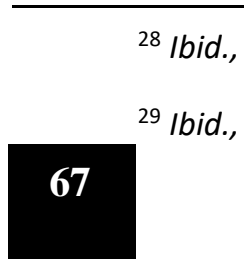


Kerjasama lintas batas membuat masyarakat Sebatik mendapatkan fasilitas layanan Pos Lintas Batas di Sei Pancang untuk dapat melintas ke Tawau dengan mudah. Sarana ini membantu warga untuk melakukan kunjungan sosial maupun perdagangan lintas batas. Namun, pada tahun 2011 PLB di Sei Pancang ditutup untuk lalu lintas orang dan dialihkan ke PLB yang ada di Nunukan. Dengan kata lain, warga Sebatik yang hendak melintas harus mengurus cap imigrasi di Nunukan sebelum berangkat ke Tawau. Hal ini sangat memberatkan warga Sebatik dari segi biaya dan waktu. Pada akhirnya penutupan PLB di Sei Pancang semakin memicu aktivitas lintas batas ilegal. ${ }^{30}$

Minimnya fasilitas serta sarana di daerah perbatasan membuat sebuah celah yang sangat besar dan menjadi suatu keuntungan terhadap Negara tetangga. Salah satu contohnya terkait siaran radio RRI yang berada di Kabupaten Nunukan memiliki satu kanal (Channel) dengan siaran radio negera tetangga, apabila siaran RRI dimatikan maka siaran-siaran dari Negara tetangga yang masuk ke Indonesia. Disatu sisi juga pemadaman bergilir di daerah perbatasan sudah hal biasa terjadi. Jadi dapat di kata wilayah perbatasan itu ibarat "sebuah rumah besar yang didalamnya banyak barang berharga namun diluarnya tidak ada pintu dan jendela yang ada cuma lubang-lubang kecil”. Kurangnya fasilitas di wilayah perbatasan dimanfaatkan kebanyakkan WNI yang melintas secara illegal, hal ini juga berdampak kepada para penegak hukum karena menyangkut hak hidup warga perbatasan. Ujar Kaharuddin Tokkong (Kabag Organisasi Kabupaten Nunukan). ${ }^{31}$

Kerja sama lintas batas sudah diterapkan, interaksi dan hubungan sosial antara masyarakat Sebatik dan Tawau semakin mudah karena adanya fasilitas Pas Lintas Batas (PLB) dan pembangunan Pos Lintas Batas. Banyak warga Sebatik, terutama di Desa Aji Kuning yang melakukan kunjungan kekeluargaan ke Tawau untuk menghadiri acara pernikahan, kematian, dan upacara adat lainnya. Setiap tanggal 17 Agustus juga diselenggarakan pertandingan olah raga seperti bulu tangkis, voli, dan sepak bola yang melibatkan warga dari kedua negara. Namun, sejak PLB di Sei Pancang ditutup dan dialihkan ke Kabupaten Nunukan, banyak warga yang pada akhirnya memilih untuk melakukan aktivitas lintas batas ilegal. Selain itu, warga juga memanfaatkan Identity Card (IC) Malaysia milik kerabat mereka untuk aktivitas lintas batas. Bahkan, diantara warga ada yang mempunyai kewarganegaraan ganda. Penutupan ini juga berimbas pada semakin berkurangnya jumlah pelintas batas resmi. ${ }^{32}$

30 Ibid.,

31 Wawancara dengan Kaharuddin Tokkong, tanggal 8 september 2017 dalam forum group discussion Pimpinan Daerah Muhammadiyah Kab.Nunukan.

${ }^{32}$ Sandy Nur Ikfal Raharjo, et.al. 2017.Op.Cit., h. 7. 


\section{Faktor Masyarakat dan Kebudayaan}

Hukum lahir karena adanya tuntutan-tuntutan instrumental terhadap pemerintah. Bagaimanapun hukum tidak mungkin dipisahkan dari keberadaan suatu pemerintah, karena tidak seperti yang pernah dikatakan Donald Black, "hukum adalah pengendalian sosial oleh pemerintah". Memang benar tidak semua aturan hukum dibuat oleh pemerintah, tetapi suatu aturan barulah dapat dikatakan aturan hukum, jika berlakunya memperoleh legitimasi suatu pemerintah. $^{33}$

Salah satu tujuan dari pengelolaan kawasan perbatasan adalah untuk memajukan kawasan tersebut agar tidak tertinggal dari kawasan lainnya di Indonesia. Memajukan taraf hidup ataupun ekonomi suatu masyarakat tentunya akan sulit dilaksanakan tanpa mengubah cara pandang dan cara hidup masyarakat itu sendiri, dan hal ini sangat erat terkait dengan kapasitas dan kapabilitas para individu yang menjadi bagian di dalamnya. Pengembangan kapasitas serta kapabilitas hanya dapat dilaksanakan dengan meningkatkan kualitas sumber daya manusia yang bersangkutan. ${ }^{34}$

Pada umumnya wilayah perbatasan selalu tertinggal dalam pembangunan dibandingkan daerah lain yang lebih mudah dijangkau, bahkan di beberapa tempat/wilayah perbatasan seakan terkesan seperti daerah tidak bertuan karena kurangnya perhatian oleh pemerintah sehingga tingkat kehidupan masyarakat di daerah tersebut tergolong miskin dan terbelakang. ${ }^{35}$

Kondisi inilah yang memaksa masyarakat perbatasan mengantungkan hidupnya di Negara tetangga aktifitas ini telah lama berlangsung. Ketidakberdayaan dalam memenuhi hak-hak warga Negara di wilayah perbatasan inilah yang melahirkan perilaku hukum yang dapat memengaruhi faktor penegakan hukum sehingga melahirkan budaya hukum di lingkungan masyarakat perbatasan.

Kekuatan-kekuatan sosial secara terus-menerus bekerja terhadap hukum, di sini merusak, di sana memperbarui; di sini memperkuat di sana memperlemah; memilih bagian-bagian 'hukum' mana yang akan dioperasikan, dan bagian hukum mana yang tidak dioperasikan. Dengan adanya tuntutan tersebut maka dapat dikatakan ini merupakan sebuah budaya hukum. Didalam sebuah peristiwa, kekuatan-kekuatan sosial tersebut tidak bekerja secara langsung pada sistem hukum. ${ }^{36}$

Warga masyarakat mempunyai kebutuhan dan membuat tuntutan, semua ini kadang-kadang menimbulkan proses hukum dan kadang-kadang tidak

33 Achmad Ali, Menguak Teori Hukum dan Teori Peradilan Termasuk Interpretasi Undang-undang, (Jakarta: Kencana, 2015). h. 152.

${ }^{34}$ Sobar Sutisna, Op.Cit, h. 21

35 Juni Suburi, Kebijakan Pengelolaan Batas Antar Negara di Kalimantan dalam Konteks Menjaga Kedaulatan Wilayah NKRI, dalam Ludiro Madu (ed.), Mengelola Perbatasan Di Dunia Tanpa Batas (Yogyakarta: Graha Ilmu, 2010). h. 122.

${ }^{36}$ Achmad Ali, 2015, Op.Cit., h. 153. 
menimbulkan proses hukum tergantung pada kultur hukum yang mereka anut. Kultur hukum berkaitan dengan bagian-bagian dari kultur umum, yaitu kebiasaan-kebiasaan, opini-opini, cara bertindak dan cara berpikir, yang mengarahkan kekuatan-kekuatan kearah atau menjauhi hukum dan cara-cara khusus. ${ }^{37}$

Hubungan kekerabatan dan perdagangan tradisional masyarakat Sebatik dan masyarakat Tawau sudah terjalin lama. Mereka melakukan kunjungan keluarga, upacara keagamaan, dan perdagangan meskipun dipisahkan oleh garis imajiner kedaulatan negara. Demi melegalkan aktivitas lintas batas tersebut, Indonesia dan Malaysia menyepakati perjanjian lintas batas berupa Basic Arrangement on Border Crossing dan Basic Arrangements on Trade and Economic Relations yang ditandatangani oleh kedua negara pada tahun $1967 .^{38}$

Seiring dengan perkembangan wilayah perbatasan Indonesia-Malaysia, pada tahun 1984 kedua negara menandatangani kesepakatan baru berupa Agreement on Border Crossing between the Republic of Indonesia and Malaysia atau yang dikenal dengan Border Crossing Agreement (BCA). Pemberlakuan BCA tahun 1984 ini sekaligus mencabut BCA tahun 1967. Pada tahun 2006, kedua negara kembali menyepakati BCA baru, tetapi belum diratifikasi. Dengan demikian, perjanjian yang berlaku saat ini adalah BCA tahun $1984 .{ }^{39}$

Berdasarkan perjanjian lintas batas (BCA) tahun 1984, aktivitas lintas batas yang dapat dilakukan oleh masyarakat perbatasan Indonesia-Malaysia adalah kunjungan keluarga, kegiatan sosial/hiburan, keperluan keagamaan, usaha/perdagangan, tugas pemerintah dan keperluan lain yang telah disetujui oleh kedua belah pihak. ${ }^{40}$

Selain BCA, kedua negara juga menyepakati Agreement on Border Trade between the Government of the Republic of Indonesia and the Government of Malaysia pada 24 Agustus 1970 di Jakarta, atau yang biasa disebut sebagai Border Trade Agreement (BTA). BTA ini merujuk pada BCA 1967 dan belum pernah direvisi hingga tahun 2016. BTA yang disepakati pada tahun 1970 merupakan landasan hukum bagi pemerintah Indonesia dan Malaysia untuk mengatur aktivitas perdagangan lintas batas di perbatasan kedua negara, termasuk di Sebatik dan Tawau. ${ }^{41}$

Keberadaan Pos Lintas Batas (PLB) dan aturan main yang diberlakukan dengan lebih ketat telah menumbuhkan sebuah "kesadaran territorial" yang dulu tidak terlalu terasakan. PLB tak pelak telah menumbuhkan pola hubungan antar penduduk pola hubungan antar penduduk di dua Negara berbeda secara lebih modern. Salah satunya adalah dengan adanya aturan main administrasi yang mengikat masyarakat untuk kembali ke tanah airnya dan mempersulit

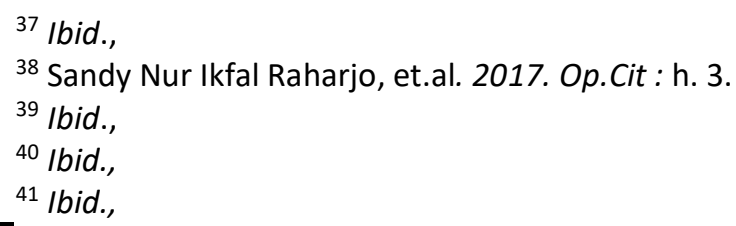


lintas manusia dari jiran ke Indonesia atau sebaliknya yang dulu terlihat liar nyaris tanpa batas. ${ }^{42}$

Adanya kerjasama ini pada awalnya dapat memberikan legitimasi hukum yang kuat bagi warga Sebatik untuk semua aktivitas lintas batas tradisionalnya menjadi legal. Namun demikian, penutupan PLB di Sebatik atas permintaan pemerintah Malaysia karena kapal yang digunakan untuk aktivitas lintas batas tidak memenuhi standar internasional, membuat kegiatan lintas batas ilegal justru semakin marak terjadi. Kemudian, masalah pengamanan di perbatasan juga belum termasuk dalam bidang yang diakomodasi dalam BCA dan BTA. Akibatnya, kegiatan lintas batas ilegal menjadi lebih sulit dikontrol. Meski demikian, seiring dengan perkembangan keamanan maritim di perbatasan Indonesia, Malaysia, dan Filipina terkait aksi radikalisme yang dilakukan ISIS di Marawi, Filipina Selatan membuat pemerintah ketiga negara bersepakat untuk meningkatkan patroli gabungan lintas batas. Hal ini tentu akan menguntungkan bagi pengamanan perbatasan Sebatik yang dekat dengan wilayah konflik. ${ }^{43}$

Di beberapa wilayah perbatasan yang demikian terisolir, peran yang dilakukan elemen adat (informal) ini justru nampak lebih besar menentukan daripada pemerintah. Adapun dalam wilayah semi-terisolir, peran lembagalembaga informal ini Nampak sederajat dengan lembaga-lembaga formal. Kondisi ini terjadi terutama karena lembaga-lembaga tersebut amat dekat dengan masyarakat dan dalam batas-batas tertentu turut menentukan aktifitas dan kehidupan keseharian masyarakat disana.

Adat telah menempatkan masyarakat secara sosial dan budaya sebagai bagian dari jaringan atau tubuh adat secara keseluruhan, yang menyebabkan mereka selalu terikat dari ikatan adat. Alih-alih terlepas, peran sentral adat dan locus dimana jaring-jaring adat itu beroperasi menjadi sebuah kebutuhan dari tiap-tiap individu yang tinggal didalamnya. ${ }^{44}$ Dibeberapa wilayah di Kalimantan utara yang masih ditinggal oleh warga asli suku dayak pandangan serta sikap nasionalisme mereka sangatlah kuat menjadi warga Negara Indonesia hal ini telah mengakar dalam adat nya. Oleh karena itu, setiap warga menyelenggarakan kegiatan adat oleh penduduk perbatasan biasanya melibatkan unsur-unsur Negara seperti personil TNI.

Peran besar perangkat adat menyebabkan kepala desa dalam hal-hal tertentu menjadi pelengkap saja. Wilayah kekuasaan ketua adat kerap meliputi wilayah yang luas, yang sebagiannya saat ini masuk dalam wilayah Malaysia. Hal itu, tidak mengherankan karena hingga kini pun ide mengenai wilayah "PanDayak" yang mencakup Malaysia dan Indonesia dalam konteks budaya masih

\footnotetext{
${ }^{42}$ Mita Noveria et.al, 2017..... Op.Cit., h. 123.

${ }^{43}$ Sandy Nur Ikfal Raharjo, et.al. 2017. Op.Cit : h. 8.

44 Ibid.,
} 
tetap ada. Tidak jarang beberapa hal yang terjadi di Malaysia diselesaikan oleh perangkat adat, atau kepala adat, yang tinggal di Indonesia. ${ }^{45}$

Oleh sebab itu, adanya hubungan kekerabatan antara warga wilayah perbatasan Indonesia dengan Malaysia melahirkan suatu kearifan lokal di masyarakat disatu sisi menguntungkan Negara Indonesia di karenakan adanya elemen vital yang tetap menjaga rasa loyalitas masyarakat tetap menjadi bagian dari NKRI. Dan kondisi inilah yang menunjukkan bahwa elemen masyarakat sendirilah yang memungkinkan terpeliharanya rasa nasionalisme di perbatasan.

Ada beberapa masyarakat yang memiliki identitas ganda sangat disayangkan oleh pihak pemerintah karena ketidaksiapan pemerintah hadir diwilayah perbatasan. Namun, pemerintah membiarkan hal tersebut untuk memudahkan akses WNI di perbatasan untuk mencukupi kebutuhan pokoknya meskipun dari segi regulasi Indonesia tidak mengakui ada warga negara beridentitas ganda. Timbul kekhawatiran pemerintah banyaknya WNI beridentitas ganda disalahgunakan oleh beberapa oknum yang memungkinkan adanya agenda terselubung dari negara Malaysia seperti halnya kasus pulau Sipadan dan Ligitan ujar letnan Kolonel Kav Valian Wicaksono. ${ }^{46}$

Klaim hak kedaulatan oleh Malaysia atas Ambalat bisa ditafsirkan sebagai upaya untuk memperluas kemenangannya ke kasus Sipadan dan Ligitan, mengingat hal itu Malaysia memegang setiap ukuran yang mungkin untuk mendapatkan bagian tertentu dari Laut Sulawesi tanpa memperhatikan prinsip 'proporsionalitas' yang tidak proporsional Langkah dilakukan dengan menggambar garis lurus lurus atau lurus kepulauan baseline dari titik Sipadan dan Ligitan sampai ke titik Sebatik, Sabah dan Sarawak. ${ }^{47}$ Adanya WNI beridentitas ganda bisa menjadi rawan apabila dibiarkan terus menerus, adanya prinsip effective occupation bisa menjadi salah satu cara pemerintah Malaysia dapat mengambil alih wilayah Indonesia, didaerah sungai semantipal dan sungai sinapad keduanya merupakan daerah OBP (Outsanding Border Problem) merupakan titik rawan dimasuki oleh oknum-oknum tidak bertanggung jawab. Oleh karena itu, TNI secara aktif melakukan sosialisasi pentingnya wawasan kebangsaan, bela negara di wilayah perbatasan untuk mengantisipasi hal yang tidak diinginkan Pemda saat ini tengah mendata WNI disana ujar letnan Kolonel Kav Valian Wicaksono. ${ }^{48}$

Dalam rangka mengurangi pelanggaran di tapal batas di wilayah IndonesiaMalaysia. Pemerintah harus memperhatikan seluruh aspek yang ada seperti ekonomi, pendidikan, kesehatan, sosial dalam menetapkan serta melaksanakan

\footnotetext{
45 Ibid.,

${ }^{46}$ Wawancara dengan letnan Kolonel Kav Valian Wicaksono, pada tanggal 11 september 2017 di kantor Kodim 0911 Kab.Nunukan

47 Marcel Hendrapati et.al, Today's Ambalat: Neglecting the Basepoints of Sipadan and Ligitan Islands for Maintaining the Equidistance Principle in the Disputed Area, Journal of East Asia and International Law, Vol 1 No 10 Januari 2017, h. 284.

${ }^{48}$ Wawancara dengan letnan Kolonel Kav Valian Wicaksono, pada tanggal 11 september 2017 di kantor Kodim 0911 Kab.Nunukan
} 
kebijakan di wilayah perbatasan dan pemerintah juga hendaknya memperhatikan sarana penunjang dalam proses penegakkan hukum di wilayah perbatasan. Kurangnya lapangan kerja merupakan salah satu pemicu banyaknya pelintas batas ilegal yang sering keluar masuk Indonesia. Oleh karena itu, kedepannya pemerintah hendaknya mampu menyediakan lapangan kerja bagi warga perbatasan.

Cakupan kegiatan lintas batas yang dibolehkan dalam BCA perlu diperluas. Selama ini, kegiatan yang dibolehkan adalah kunjungan keluarga, kegiatan sosial/hiburan, keperluan keagamaan, usaha/ perdagangan, tugas pemerintah dan keperluan lain yang telah disetujui oleh kedua belah pihak. Kegiatan lintas batas yang perlu ditambah adalah keperluan kesehatan (berobat), pendidikan (sekolah), dan pekerjaan yang selama ini sudah dilakukan dan dibutuhkan oleh warga perbatasan. Untuk aktivitas-aktivitas di atas, perlu ada kesepakatan bilateral untuk penyetaraan perlakuan khusus untuk warga perbatasan. Komoditas barang dalam BTA perlu diperluas. Selama ini, komoditas perdagangan yang dibolehkan dari sisi Indonesia adalah produk pertanian dan produk lain, kecuali mineral oil dan ores (minyak dan bahan/bijih tambang). Komoditas tersebut perlu diperluas menjadi produk pertanian dan olahannya, produk perikanan dan olahannya, serta produk industri rumah tangga. Adapun komoditas yang perlu dilarang adalah bahan tambang, barang bercukai seperti rokok, serta makanan dan minuman beralkohol. ${ }^{49}$

Nilai kuota perdagangan lintas batas (treshold value) perlu dinaikkan dan di konversi dari 600 ringgit menjadi menjadi 500 dolar Amerika Serikat. Hal ini didasarkan pada Produk Domestik Regional Bruto (PDRB) Perkapita Kabupaten Nunukan yang mencapai Rp 93.045.780 pertahun atau Rp7.753.815 perbulan (setara dengan sekitar 500 dolar). Di ubahnya mata uang dari Ringgit Malaysia menjadi Dollar Amerika di nilai cukup memberi keuntungan penduduk perbatasan dan perubahan ini secara politik lebih netral dan lebih stabil nilai tukarnya. ${ }^{50}$

Beberapa kalangan dari negara Malaysia menyadari ketergantungan dalam beberapa hal. Hal ini dapat mengubah cara pandang mereka terhadap negara Indonesia sehingga dapat memberikan dampak positif terhadap kedaulatan wilayah perbatasan itu sendiri. Dari segi Indonesia itu sendiri, ketergantungan Malaysia sebenarnya merupakan potensi terbesar yang tidak pernah di lirik oleh pemerintah itu sendiri, potensi ini mampu menaikkan posisi Indonesia dalam melakukan hubungan dengan Malaysia.

Untuk mengurangi ketergantungan barang dari Malaysia, pemerintah Indonesia perlu menggandeng pihak swasta untuk membangun industri di kawasan perbatasan sesuai dengan potensi lokal yang ada. Pihak swasta yang mau terlibat dapat diberikan insentif, misalnya pengurangan pajak dan kemudahan untuk membuka usaha/industri di wilayah Indonesia yang lain.

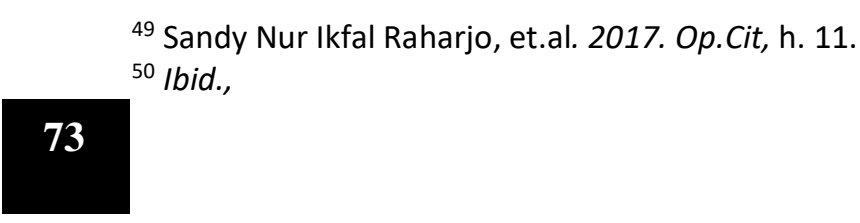


Oleh sebab itu, Diperlukan suatu lembaga di daerah yang fokus pada masalahmasalah yang ada di kawasan perbatasan. Salah satu upaya yang harus dilakukan adalah merevitalisasi peran Badan Pengelola Perbatasan Daerah (BPPD) di tingkat provinsi maupun kabupaten. ${ }^{51}$ Dengan demikian ancaman terhadap kedaulatan NKRI, yang diakibatkan kesenjangan sosial serta penegakkan hukum diwilayah perbatasan dapat dikurangi dan bahkan dihilangkan, karena pada hakikatnya hukum itu membawa kebahagiaan.

\section{PENUTUP}

\section{A. Kesimpulan}

Berdasarkan pembahasan diatas maka, disimpulkan sebagai berikut:

1) Kurangnya fasilitas memadai di kawasan perbatasan dan kondisi yang masih tertinggal mengakibatkan warga perbatasan di Kalimantan Utara yang berbatasan langsung dengan Negara Malaysia Bagian Timur mengantungkan hidup ke negara tetangga. Pasca pentupan pos lintas batas di Sei Pancang berdampak signifikan terhadap warga perbatasan yang ingin melintas. Hal ini dapat memunculkan banyaknya pelangggar batas illegal. Kehadiran negara di wilayah perbatasan sangat disadari oleh masyarakat itu sendiri sehingga banyak WNI memiliki ketergantungan terhadap negara tetangga, banyaknya fasilitas yang disediakan oleh negara tetangga mengakibatkan banyaknya WNI mengadu nasib ke negara tetangga sehingga dapat mempengaruhi degradasi nasionalisme WNI perbatasan.

\section{B. Saran}

1) Regulasi yang dikeluarkan pemerintah terkait pengembangan wilayah perbatasan mengakibatkan kurang efektifnya suatu hukum yang berjalan di wilayah perbatasan. Oleh karena itu, sangat dibutuhkan harmonisasi hukum agar tercipta sinergi antar sesama lembaga dalam mengelola perbatasan, inti masalah yang terjadi diwiliyah perbatasan terkait kesejahteraan dalam hal ini masalah ekonomi. Pembaruan hukum sangat diperlukan karena aturan-aturan terkait perbatasan sudah tidak relevan lagi dalam kehidupan masyarakat perbatasan. Kompleksitas masalah yang terjadi di wilayah perbatasan merupakan "Pekerjaan Rumah (PR)" pemerintah pusat dalam menyelesaikan hal tersebut, seharusnya pemerintah menerapkan suatu kebijakan tertentu dalam menangani wilayah perbatasan. Kedepannya pemerintah hendaknya mengeluarkan suatu kebijakan khusus dalam menangani wilayah perbatasan dan kebijakan tersebut mampu mewadahi seluruh aspek yang ada.

51 Ibid., 


\section{DAFTAR PUSTAKA}

Achmad Ali. Menguak Teori Hukum (Legal Theory) \& Teori Peradilan (Judicialprudence): Termasuk Interpretasi Undang-Undang (Legisprudence). Jakarta: Kencana, 2015.

Asren Nasution. Pertahanan Negara Di Wilayah Pesisir Perspektif Pengembangan Wilayah. Jakarta: Prenada, 2011.

Eda Ervina. 2014. Cerita Hilangnya Patok Batas Indonesia-Malaysia di Nunukan, http://www.merdeka.com/peristiwa/cerita-hilangnya-patok-batas-indonesia -malaysia-dinunukan/kapolda-kaltim-akan-tinjau-pos-perbatasan.html

Jimly Asshiddiqie, 2010, Penegakan Hukum, http://www.jimly.com/makalah /namafile/56/Penegakan_Hukum.pdf

Ludiro Madu dkk. Mengelola Perbatasan Indonesia di Dunia Tanpa Batas Isu, Permasalahan dan Pilihan Kebijakan. Yogyakarta: Graha Ilmu, 2010.

Marcel Hendrapati et.al. Today's Ambalat: Neglecting the Basepoints of Sipadan and Ligitan Islands for Maintaining the Equidistance Principle in the Disputed Area. Journal of East Asia and International Law, Vol 1 No 10 Januari 2017.

Mita Noveria et.al. Kedaulatan Indonesia Di Wilayah Perbatasan Perspektif Multidimensi. Jakarta: Yayasan Pustaka Obor, 2017.

Mochtar Kusumaatmadja. Pengantar Hukum Internasional. Bandung: Alumni, 2012.

Muhammad Syafei. Pengaturan Pengelolaan Kawasan Perbatasan Kalimantan Barat-Sarawak Malaysia. Disertasi Universitas Hasanuddin. Makassar, 2012.

Odelia Sinaga. 2014. Modus Malaysia Kuasai Desa di Perbatasan Indonesia.https://m.tempo.co/read/news/2014/11/17/078622324/modusmalaysia-kuasai-desa-di-perbatasan-indonesia

Purnomo Yusgiantoro. Pengelolaan Perbatasan Mengsinergikan Keamanan dan Kesejahterahan. Tabloid Diplomasi. 15 Februari-14 Maret 2013.

Sandy Nur Ikfal Raharjo. et al. Strategi Peningkatan Kerja Sama Lintas Batas (Border Crossing Agreement) Indonesia Malaysia. Jakarta: Lembaga Ilmu Pengetahuan Indonesia, 2017.

Satjipto Rahardjo. Pemanfaatan Ilmu-ilmu Sosial Bagi Pengembangan Ilmu Hukum. Jakarta: Genta Publishing, 2010.

Soerjono Soekanto. Faktor-faktor Yang Mempengaruhi Penegakan Hukum. Jakarta: Rajawali Pers, 2013.

Suryanto Suryokusumo et.al. Konsep Sistem Pertahanan Nonmiliter: Suatu Sistem Pertahanan Komplemen Sistem Pertahanan Militer dalam Pertahanan Rakyat Semesta. Jakarta: Yayasan Pustaka Obor Indonesia, 2016. 